\title{
The Attorney General, Politics, and the Public Interest: Contributions to an Evolving Constitutional Convention
}

Michael Murphy

\begin{abstract}
The prosecutorial independence of the Attorney General (AG) is a firmly established constitutional convention in Canada, but it is also an evolving convention, subject to ongoing contestation and debate. This article is a contribution to that debate. It defends a normative constitutional framework wherein the AG's authority to make final decisions in matters of criminal prosecution is balanced against a corresponding duty to consult with cabinet and the prime minister on the public interest implications of prosecutorial decisions when the circumstances warrant. Within this normative framework, respectful contestation and debate amongst ministers, the prime minister, and the AG in determining the public interest merits of prosecution is welcomed, even encouraged, and if conducted with the requisite integrity, objectivity, and transparency, it is regarded not as a threat but as a valuable check and balance on AG independence and an indispensable form of quality control on the exercise of prosecutorial discretion.
\end{abstract}

Keywords: Prosecutorial independence, Shawcross doctrine, SNC-Lavalin, Trudeau, Wilson-Raybould, partisanship, ministerial consultation, remediation agreements

\section{Résumé}

L'indépendance du procureur général (PG) en matière de poursuites est une convention constitutionnelle fermement établie au Canada. Ceci dit, il s'agit aussi d'une convention en évolution qui est sujette à des contestations et à des débats permanents. Le présent article se veut une contribution à ce débat. Il défend plus précisément un cadre constitutionnel normatif dans lequel le pouvoir du PG de prendre des décisions finales en matière de poursuites criminelles est contrebalancé par une obligation de consulter - lorsque les circonstances le justifient - le premier ministre et son cabinet face aux répercussions que les décisions de lancer des poursuites peuvent avoir sur l'intérêt public. Dans ce cadre normatif, la contestation et les débats respectueux, dans l’optique de déterminer le bien-fondé d'une

\footnotetext{
* My thanks to Jonathan Swainger, the Journal's editor, and anonymous referees for comments and suggestions that were enormously helpful with my revisions.
}

Canadian Journal of Law and Society / Revue Canadienne Droit et Société, 2022, Volume 37, no. 2, pp. 209-228. doi:10.1017/cls.2021.42

(C) The Author(s), 2022. Published by Cambridge University Press on behalf of the Canadian Law and Society Association. This is an Open Access article, distributed under the terms of the Creative Commons Attribution licence (https://creativecommons.org/licenses/by/4.0/), which permits unrestricted re-use, distribution, and reproduction in any medium, provided the original work is properly cited. 
poursuite pour l'intérêt public, entre les ministres, le premier ministre et le PG sont les bienvenus, voire encouragés, s'ils sont menés avec l'intégrité, l'objectivité et la transparence requises. Dans cette voie, de tels contestations et débats ne sont pas considérés comme une menace, mais comme un contrôle et un équilibre précieux de l'indépendance du PG et une forme indispensable de contrôle de la qualité de l'exercice du pouvoir discrétionnaire en matière de poursuite.

Mots clés : indépendance du procureur, doctrine Shawcross, SNC-Lavalin, Trudeau, Wilson-Raybould, partisanerie, consultation ministérielle, accord de réparation

\section{Introduction}

Early in 2019, Prime Minister Justin Trudeau's Liberal government was pitched headlong into the most serious crisis of its first term in office. The crisis centred around allegations that Trudeau, some of his closest advisors and ministers, and Privy Council Clerk Michael Wernick had pressured Attorney General (AG) Jody WilsonRaybould to help Quebec engineering firm SNC-Lavalin secure a deferred prosecution agreement and avoid criminal charges connected to its past business dealings with the regime of Libyan dictator Muammar Gaddafi. ${ }^{1}$ As Wilson-Raybould herself testified before the House of Commons Standing Committee on Human Rights, "[f]or a period of approximately four months, between September and December of 2018, I experienced a consistent and sustained effort by many people within the government to seek to politically interfere in the exercise of prosecutorial discretion in my role as the Attorney General of Canada in an inappropriate effort to secure a deferred prosecution agreement with SNC-Lavalin." ${ }^{2}$ While Trudeau was quick to insist that nothing improper had taken place, and that the government's sole intention was to avoid the serious job losses that would likely follow a criminal conviction and SNC-Lavalin's debarment under Canada's Integrity Regime, ${ }^{3}$ critics asserted that the Liberal government was actively subverting the rule of law in order to assist a corporate ally, and to secure its prospects for re-election in a key federal riding in Quebec. Calls soon came for Trudeau's resignation, a public inquiry, a criminal investigation by the RCMP (Royal Canadian Mounted Police), and even for the fall of the government. ${ }^{4}$

1 Robert Fife, Steven Chase, and Sean Fine, "PMO Pressed Wilson-Raybould to Abandon Prosecution of SNC-Lavalin; Trudeau Denies his Office 'Directed' Her," Globe and Mail, February 7, 2019, https://www.theglobeandmail.com/politics/article-pmo-pressed-justice-minister-toabandon-prosecution-of-snc-lavalin/. Deferred prosecution agreements (also referred to as remediation agreements) were introduced as an amendment to the Criminal Code in 2018. See Justice Canada, Criminal Code (RSC, 1985, c C-46), Part XXII.1, https://laws-lois.justice.gc. ca/eng/acts/c-46/index.html.

2 Wilson-Raybould, Jody, Evidence Presented to the Canadian House of Commons Standing Committee on Human Rights, Wednesday, February 27, 2019, Number 135, 1st Session, 42nd Parliament, at 2, https://www.ourcommons.ca/DocumentViewer/en/42-1/JUST/meeting-135/evidence.

3 See Canada, Integrity Regime, Guide to the Ineligibility and Suspension Policy,: https://www.tpsgcpwgsc.gc.ca/ci-if/guide-eng.html.

4 Canadian Press, “Tories, NDP Demand Full Public Inquiry Into SNC-Lavalin Affair," February 19, 2019, https://www.huffingtonpost.ca/entry/snc-lavalin-public-inquiry_ca_5cd58a12e4b07bc 72979041b; John Ibbitson, “Trudeau Has Lost the Moral Mandate to Govern,” Globe and Mail, February 7, 2019, https:/www.theglobeandmail.com/opinion/article-trudeau-has-lost-the-moralmandate-to-govern/. 
Political fallout from the scandal also was swift, beginning with the resignation of Trudeau's principal secretary and most trusted advisor Gerald Butts, and soon followed by the departure of Privy Council Office (PCO) head Michael Wernick. ${ }^{5}$ The Liberal cabinet was seriously fractured by the resignation of Wilson-Raybould and another high-profile minister, Jane Philpott, both of whom were subsequently expelled from the Liberal caucus. ${ }^{6}$ Perhaps the most serious damage was done to Trudeau's already fragile reputation as a transformational Prime Minister committed to a more ethical manner of governing in Ottawa, but his government also suffered a serious loss of public confidence and, following a difficult election campaign in October of 2019, found itself reduced to minority status while losing the popular vote to the federal Conservatives.

Two months after the election, SNC-Lavalin reached a settlement with Crown prosecutors whereby the company's construction arm pleaded guilty to one charge of fraud and was issued a $\$ 280$ million fine in exchange for the withdrawal of criminal corruption charges against the parent company and its global marketing arm. ${ }^{8}$ While this marked the formal end of the SNC-Lavalin affair, in the aftermath of the scandal we are left with a number of pressing questions. Many of these, of course, are specific to the scandal itself, including the core question of whether, or to what extent, Trudeau and other government officials were guilty of partisan interference in the exercise of prosecutorial discretion. ${ }^{9}$ However, my primary aim in this article is not to stake out a comprehensive position on the propriety of official conduct in the SNC-Lavalin affair but instead to engage with a more general set of questions that have emerged in connection with this narrower debate. These include the nature and limits of prosecutorial independence, the appropriate role of cabinet ministers (and the prime minister) in public interest consultations informing the exercise of the AG's prosecutorial discretion, and where to draw the line between legitimate public interest and improper partisan political considerations in those consultations.

5 Catharine Tunney, "Michael Wernick to Step Down as Clerk of Privy Council, Cites Lack of 'mutual trust' with Opposition,” CBC News, March 18, 2019, https:/www.cbc.ca/news/politics/ wernick-election-panel-snc-1.5060834

6 Kathleen Harris, "Trudeau Ejects Wilson-Raybould, Philpott from Liberal caucus," CBC News, April 2, 2019, https://www.cbc.ca/news/politics/liberals-wilson-raybould-philpott-caucus1.5080880.

7 Éric Grenier, "Is Trudeau in for Another Hit in the Polls Because of the SNC-Lavalin Ethics Report?" CBC News, August 15, 2019, https://www.cbc.ca/news/politics/grenier-snclavalin-polls1.5247244; Cousins, Ben, "Trudeau Nabs Minority Government, Loses the Popular Vote, in Tumultuous Campaign,” CTV News, October 21, 2019, https://election.ctvnews.ca/trudeau-nabsminority-government-loses-the-popular-vote-in-tumultuous-campaign-1.4649117.

$8 \quad$ Basem Boshra, "SNC-Lavalin Pleads Guilty to Fraud, Will Pay \$280-Million Fine for Company’s Past Work in Libya," CTV News, December 18, 2019, https://montreal.ctvnews.ca/snc-lavalinpleads-guilty-to-fraud-will-pay-280-million-fine-for-company-s-past-work-in-libya-1.4734945.

9 For contrasting positions on this question see Mario Dion, Trudeau II Report (Ottawa: Office of the Conflict of Interest and Ethics Commissioner, Parliament of Canada, 2019), 53, 57, http://ciecccie.parl.gc.ca/Documents/English/Public\%20Reports/Examination\%20Reports/Trudeau\%20II\% 20Report.pdf; and Kate Bezanson, "Constitutional or Political Crisis? Prosecutorial Independence, the Public Interest, and Gender in the SNC-Lavalin Affair," UBC Law Review 52, no. 3, (2019): 761815 . 
The prosecutorial independence of the AG is a firmly established constitutional convention in Canada, ${ }^{10}$ but it is also an evolving convention, subject to ongoing contestation and debate, and this article is a contribution to that debate. ${ }^{11}$ I defend three main arguments: first, that the prosecutorial independence of the AG must be balanced against a corresponding duty to consult with cabinet and the prime minister on the public interest implications of prosecutorial decisions when the circumstances warrant; second, that cabinet ministers and the prime minister have both the right and the responsibility to proactively raise pressing public interest considerations with the AG, to assure themselves that those considerations have been adequately weighed and understood, and, if necessary, to engage the AG in vigorous debate and contestation regarding where the public interest lies in the exercise of prosecutorial discretion; and third, that there is nothing inherently problematic (or illegitimate) about ministers making public interest representations to the AG that would also (and unavoidably) have the effect of advancing some private interest.

The article is divided into five sections. Section one briefly examines the nature and function of prosecutorial independence in Canada. Section two raises the question of the AG's duty to consult with cabinet and the prime minister. Section three seeks to clarify the distinction between public interest and partisan considerations and to locate the place of private interests in ministerial consultations with the AG. Section four examines the appropriate standard of conduct for ministers engaged in consultations with the AG, and section five offers a brief conclusion.

10 See John Edwards, The Attorney General, Politics and the Public Interest (London: Sweet \& Maxwell, 1984); Philip Stenning, Appearing for the Crown: A Legal and Historical Review of Criminal Prosecutorial Authority in Canada (Cowansville: Brown Legal Publications, 1986); Roy McMurtry, "The Office of the Attorney General," in The Cambridge Lectures. Selected Papers Based upon Lectures Delivered at the Cambridge Conference of the Canadian Institute for Advanced Legal Studies, 1979, ed. Derek Mendes da Costa (Toronto: Butterworths, 1981), 1-7; Ian G. Scott, "The Role of the Attorney General and the Charter of Rights," Criminal Law Quarterly 29, (1987): 18799; Ian G. Scott, "Law, Policy and the Role of the Attorney General: Constancy and Change in the 1980s," University of Toronto Law Journal 39, (1989): 109-26; Canada, Law Reform Commission, "Controlling Criminal Prosecutions: The Attorney General and the Crown Prosecutor," Working Paper 62 (Ottawa: Law Reform Commission of Canada, 1990); Kent Roach, "Not Just the Government's Lawyer: The Attorney General as Defender of the Rule of Law," Queen's Law Journal 31 (2006): 598-643; Kent Roach, “The SNC Lavalin Controversy: The Shawcross Principle and Prosecutorial Independence," Social Science Research Network (SSRN), April 5, 2019, http:// doi.org/10.2139/ssrn.3367097; Marc Rosenberg, "The Attorney General and the Administration of Criminal Justice," Queen's Law Journal 34, no. 2 (2009): 813-62; Anne McLellan, "Review of the Roles of the Minister of Justice and Attorney General of Canada," report commissioned by the Prime Minister of Canada," June 28, 2019, https://pm.gc.ca/en/news/backgrounders/2019/08/14/ review-roles-minister-justice-and-attorney-general-canada. The Supreme Court of Canada recognized this convention as a constitutional principle in Krieger $v$ Law Society of Alberta [2002] 3 SCR 372. As Stenning reminds us, this principle was "not well established until well into the 20th Century." See Philip Stenning, Appearing for the Crown, 290. For elaboration see J. Ll. J. Edwards, The Law Officers of the Crown (London: Sweet and Maxwell, 1964), 177-214.

11 See Roach, "The SNC Lavalin Controversy," 2; Craig Forcese, “Attorney General Independence: The Forgotten Basford Standard and its National Security Nexus," Intrepid Blogsite, May 1, 2019, https:/www.intrepidpodcast.com/blog/2019/4/30/attorney-general-independence-the-forgottenbasford-standard-and-its-national-security-nexus; Bezanson, "Constitutional or Political," 763; and Rosenberg, “The Attorney General," 850. 


\section{The Prosecutorial Independence of the AG in Canada}

The AG's oversight of the federal criminal prosecution function in Canada includes the authority to initiate, conduct, or discontinue criminal prosecutions on behalf of the Crown. Since 2006, this responsibility has been delegated to an independent Director of Public Prosecutions (DPP), who exercises this authority "under and on behalf of the Attorney General." ${ }^{12}$ In practice, then, the AG generally has very little involvement either in individual prosecutions or the routine administration of criminal justice, these routine functions mainly being performed by the DPP. However, the AG retains the authority, in exceptional circumstances, to intervene in the exercise of the public prosecution function, either by issuing a directive to the DPP regarding a given prosecution or by assuming direct control over the conduct of that prosecution. ${ }^{13}$ In the interests of transparency and accountability, the AG must first consult with the DPP and confirm any decision to intervene by means of a written notice in the Canada Gazette. ${ }^{14}$ Attorney General interventions can take many forms, including the termination of an ongoing prosecution, a decision against prosecution in the first instance, or a directive to negotiate a deferred prosecution agreement - the outcome sought in the SNC-Lavalin affair. In all cases, the fundamental objective of intervention must be the advancement or protection of the "public interest and the fair administration of justice." 15

Given the significant power this discretionary authority grants to the AG, and the potential danger it poses to the independence of the DPP and to public confidence in the integrity of the criminal justice system, the expectation is that interventions will be extremely rare, and restricted to a select number of cases with highly significant implications for the public interest. ${ }^{16}$ When exercising this authority, the AG must do so with honesty and integrity, and in strict accordance with principles of fairness and objectivity. Moreover, since the AG in Canada is also an elected politician who sits in cabinet, it is particularly important that they exercise their prosecutorial discretion independently of any improper political pressures or considerations. ${ }^{17}$ The prosecutorial independence of the AG is a fundamental pillar of the rule of law in Canada. It serves to ensure that the law is applied equally and impartially to all, and in so doing it helps maintain public

12 Canada, An Act Respecting the Office of the Director of Public Prosecutions (SC 2006, c 9, s 121), s 3(3), Justice Laws Website https://laws-lois.justice.gc.ca/eng/acts/d-2.5/FullText.html.

13 The Attorney General (AG) may also "issue directives respecting the initiation or conduct of prosecutions generally"; ibid. at s $10(2)$.

14 Canada, An Act Respecting, at ss 10, 13-15.

15 Rosenberg, "The Attorney General," 827, quoting former Ontario AG Roy McMurtry; see also I. G. Scott, "Law, Policy," 121; and Canada, Public Prosecution Service, Public Prosecution Service of Canada Deskbook, 2014, Part 2.3, pp. 3-5, https://www.ppsc-sppc.gc.ca/eng/index.html.

16 Canada, Law Reform Commission, "Controlling Criminal Prosecutions," 17; Edwards, The Attorney General, 50; Canada, Public Prosecution Service, Public Prosecution, Part 1.1, pp. 9-12; Kenneth Jull, "The Right and the Wrong Way To Seek Remediation Agreements," Toronto Law Journal, (March 2019), 9-10, https://www.grllp.com/publications/Jull_Toronto_Law_JournalMar_2019.pdf. To date, no federal AG has exercised this authority in relation to a specific criminal prosecution in Canada, although a small number of general directives have been issued. Specific directives have been issued only five times at the provincial level, three of them in relation to the same case in British Columbia. See McLellan, "Review of the Roles," 20, 48.

17 Roach, "The SNC Lavalin Controversy," 2-3; Krieger v Law Society at ss 3, 29-30, 48. 


\section{4}

Michael Murphy

confidence that the administration of justice is neither arbitrary nor in thrall to the partisan interests or vendettas of the government in power. ${ }^{18}$

The most enduringly influential encapsulation of the prosecutorial independence of the Attorney General, which John Edwards refers to as "the modern exposition of the constitutional position of the Attorney-General," 19 is the Shawcross doctrine, first articulated by Sir Hartley Shawcross in 1951. It bears quoting at length:

I think the true doctrine is that it is the duty of an Attorney-General, in deciding whether or not to authorize the prosecution, to acquaint himself with all the relevant facts, including, for instance, the effect which the prosecution, successful or unsuccessful as the case may be, would have upon public morale and order, and with any other considerations affecting public policy.

In order so to inform himself, he may, although I do not think he is obliged to, consult with any of his colleagues in the Government; and indeed, as Lord Simon once said, he would in some cases be a fool if he did not. On the other hand, the assistance of his colleagues is confined to informing him of particular considerations, which might affect his own decision, and does not consist, and must not consist in telling him what that decision ought to be. The responsibility for the eventual decision rests with the AttorneyGeneral, and he is not to be put, and is not put, under pressure by his colleagues. ${ }^{20}$

The Shawcross doctrine has become the gold standard of prosecutorial independence in Canada and other Commonwealth jurisdictions, and its central guidelines are widely cited by legal scholars and Crown law officers, and within government circles. ${ }^{21}$ Yet despite this consensus on the central importance of the Shawcross doctrine, what became clear during the course of the SNC-Lavalin affair is that there are very different ways of interpreting and applying the doctrine's specific guidelines, and thus very different readings of the nature and parameters of the prosecutorial independence of the $A \mathrm{G}^{22}$ In the coming sections, I will focus on three of the most important areas where differences have emerged: the role of consultation in the AG's exercise of prosecutorial discretion, the distinction

18 McMurtry, "The Office," 6; Rosenberg, “The Attorney General," 861-62; I. G. Scott, "Law, Policy," 119-20; Roach, "Not Just the Government's Lawyer," 609; Roach, "Prosecutorial Independence and Accountability in Terrorism Prosecutions," Criminal Law Quarterly 55, no. 4 (2010): 486-507, at 492-93.

19 Edwards, The Law Officers, 223.

20 United Kingdom, House of Commons Debates, vol 483, cols 683-84, (29 January 1951). The most widely regarded exposition of this principle by a Canadian AG is contained in a 1978 speech by Ron Basford in the Canadian House of Commons. See Canada, Hansard, March 17, 1978, at 3881-83.

21 Edwards, The Law Officers, 223; Canada, Law Reform Commission, "Controlling Criminal Prosecutions," 9-10; Rosenberg, "The Attorney General," 821; Roach, "Prosecutorial Independence," 501-503; I. G. Scott, "Law, Policy," 120-21; Craig Forcese, "L’Affaire SNC-Lavalin: The Public Law Principles," Public Law Blog, Saturday, February 9, 2019, http://craigforcese. squarespace.com/public_law_blog/; Dion, Trudeau II Report, 51-52; McLellan, "Review of the Roles," 14-15.

22 See, for example, Roach, "The SNC Lavalin Controversy," 2; Forcese, "L'Affaire SNC-Lavalin”; Forcese, “Attorney General Independence"; McLellan, "Review of the Roles," 33-34; and Bezanson, "Constitutional or Political," 763. 
between public interest and partisan political considerations in those consultations, and the appropriate standards of conduct for government ministers taking part in those consultations.

\section{A Duty to Consult With the Prime Minister and Cabinet? ${ }^{23}$}

One of the key questions surrounding the principle of prosecutorial independence is whether or not the AG has a duty to consult with government colleagues when exercising their prosecutorial discretion. The Shawcross doctrine offers the following guidance: in the course of ascertaining the potential impact of prosecution on the public interest, the AG "may, although I do not think he is obliged to, consult with any of his colleagues in the Government; and indeed, as Lord Simon once said, he would in some cases be a fool if he did not." 24 There is a decided tension in this statement which suggests that, on the one hand, there is no obligation to consult, while on the other, that only a foolish AG would fail to appreciate that, in some cases, failing to consult would be a grave dereliction of their responsibility to safeguard the public interest. ${ }^{25}$ Nevertheless, the prevailing interpretation of Shawcross is that consultation is optional, subject only to the discretion of the AG. ${ }^{26}$ As the McLellan report concludes, " $[t]$ he original statement of the Shawcross Doctrine implies that it is the Attorney General who decides whether or not to consult. This is consistent with the idea that there is no obligation to consult and the consultation only occurs where the Attorney General sees value in it." 27

I wish to challenge this conclusion, and to argue, first of all, that the Shawcross doctrine does not necessarily rule out a duty to consult, but second and more importantly, that as a matter of principle, this is the more defensible position, and that an AG who failed to uphold this responsibility would be in serious breach of their constitutional responsibility to serve as a guardian of the public interest in matters of criminal prosecution. ${ }^{28}$ Support for this alternative view can be found in one of Edwards's earlier works, The Law Officers of the Crown (1964), in a series of passages where he considers a famous letter penned [to] the Times of London by

23 Following Edwards (The Attorney General, 56-57), the AG is free to consult with a wide variety of individuals, but in this article, I focus exclusively on consultation with cabinet and the prime minister.

24 United Kingdom, House of Commons Debates, vol 483, cols 683-84.

25 To quote from Lord Simon: "I should regard him not as a good Attorney-General but as a fool if he were to start on his own motion prosecutions which involve grave matters of public concerntreason, sedition, corruption and the like-I should regard it as a very grave mistake if he did such a thing without knowing that, in the view of his colleagues, public policy was not offended by undertaking such prosecution"; cited in Edwards, The Law Officers, 215-16.

26 See, for example, Edwards, The Attorney General, 56-57; John Edwards, "Ministerial Responsibility for National Security as it Relates to the Offices of Prime Minister, Attorney General and Solicitor General of Canada," (Ottawa: Minister of Supply and Services Canada, 1980), 68; I. G. Scott, "Law, Policy," 121; Roach, "Prosecutorial Independence," 477-78; and Dion, Trudeau II Report, 14, 53.

27 McLellan, "Review of the Roles," 35; see also Stenning, Appearing for the Crown, 294; and Rosenberg, "The Attorney General," 821.

28 On the AG's role as guardian of the public interest, see Canada, Law Reform Commission, "Controlling Criminal Prosecutions," 19-22; Edwards, "Ministerial Responsibility," 68; and I. G. Scott, "Law, Policy," 119-20. 
Lord Cyril Asquith. ${ }^{29}$ In his letter, Lord Asquith questions the wisdom of wholly excluding the British cabinet from the process of deciding whether leaders of the Ulster movement should be prosecuted for treason, and asks rhetorically: "Is it really suggested that the Law Officers of the day should have assumed the undivided responsibility for instituting or withholding proceedings and that the Cabinet could have claimed no voice in a decision on which the whole political future of Ireland might have turned?" ${ }^{0}$ Edwards sees in this quote a rejection of "two extreme views, namely, that members of Cabinet are in no circumstances entitled to be consulted on the desirability of prosecution, and, on the other hand, the view that they are always so entitled." 31 What this suggests, then, is that in cases with significant implications for the public interest, cabinet officials are entitled to be consulted on the wisdom of prosecution, which in turn implies a corresponding duty of the AG to engage in those consultations.

Additional support for this view comes a little further along in the text, where Edwards cites, with approval, a statement on the constitutional position of the AG made in the Parliament of the United Kingdom on December 18, 1924, by then Prime Minister Stanley Baldwin: "it is the duty of the Attorney-General, in the discharge of his responsibilities so entrusted to him, to inform himself of all the relevant circumstances which might properly affect his decision: when the proposed prosecution is of such a character that matters of public policy are, or may be, involved, it is the duty of the Attorney-General to inform himself of the views of the government or of the appropriate Minister before coming to a decision." ${ }^{32}$ This statement would appear to contradict the Shawcross stipulation that the AG be not obliged to consult with colleagues in government. ${ }^{33}$ However, this apparent contradiction dissolves if we read the Shawcross doctrine as rejecting a universal obligation to consult on every case that arises in favour of a more circumscribed duty to consult when the circumstances warrant. Specifically, in cases where there are no reasonable grounds to believe that other members of government might have vital information to offer on the public interest implications of prosecution, the AG is under no obligation to consult; however, in cases where ministers are likely to possess such information, consultation is no longer optional but required, and it is the constitutional duty of the AG to see that it is undertaken. This reading of Shawcross bears a certain surface similarity to the earlier cited conclusion from the McLellan report, but there are two major differences: first, it does not assume that the AG is the only one who should have a voice in determining whether there is value in consultation, a view I will expand upon in section four, and second, in those

29 Edwards, The Law Officers, 213-23. In his later work, Edwards makes no mention of any such duty, and all indications are that he supported the view that AG consultation on the public interest implications of criminal prosecutions is optional.

Ibid., 213-14 n. 48.

Ibid., 213-14 n. 48.

Ibid., 214 (emphasis added). Baldwin was, nevertheless, unequivocal that Cabinet has no legitimate role to play in directing prosecutorial decisions, and that the AG alone is empowered to make final decisions in these matters (ibid., 213-15).

33 Edwards himself makes no mention of the apparent inconsistency between Baldwin and Shawcross, and simply concludes that the two doctrines are "in keeping with" one another; ibid, 223. 
situations where consultation is warranted, it is to be regarded not as optional but as mandatory.

Questions of interpretation aside, as a matter of principle it is surely appropriate to conclude that if there are reasonable grounds to believe that the prime minister or a member of cabinet might be in possession of knowledge or expertise that would shed valuable light on the public interest implications of any given prosecutorial decision, then it is the duty of the AG to pursue those consultations, and if this cannot be made consistent with Shawcross, then perhaps it is time to question the wisdom of this particular aspect of the doctrine. Driving this conclusion is the possibility that, in the absence of consultation, the AG may lack the necessary information or background to make a properly informed decision, which could have harmful, even potentially disastrous, consequences for the public interest. This might seem more obvious in prosecutions linked to critical issues of national security or highly sensitive and complex matters of international relations, where the stakes are very high and sound determinations of the public interest depend upon the possession of highly specialized knowledge or expertise and on access to information that is closely guarded or even classified. ${ }^{34}$ However, it seems no less true of prosecutions linked to vital matters of public health and safety, domestic civil strife, economic and financial stability, domestic constitutional crises, and the like. ${ }^{35}$ For in these areas, too, a properly informed determination of the public interest and the avoidance of very substantial public harms may depend upon information and expertise currently in the possession of other government ministers by virtue of their specific training, experience, access to specialized bureaucratic resources, or network of professional and community contacts.

Imagine a case in which there are reasonable grounds to believe that the ministers of health and public safety are in possession of critical information on how a given prosecution might compromise the government's ongoing efforts to fight a deadly pandemic, for example, by undermining public trust or provoking widespread panic. Does the AG have an obligation to consult with those ministers? The answer, if we are to cleave to the standard reading of the Shawcross doctrine, is that no such obligation exists, regardless of the stakes involved, and if the end result is an ill-informed prosecutorial decision with harmful consequences for public well-being, the most that can be said is that the AG was guilty of poor judgment, not of any fundamental breach of their constitutional duty. In my view this reply is at best unsatisfactory and at worst irresponsible in failing to establish and uphold a

34 For discussion on these points see Stenning, "Discretion, Politics, and the Public Interest in HighProfile Criminal Investigations and Prosecutions," Canadian Journal of Law and Society 24, no. 3 (2009): 337-66, at 360-65; Philip Stenning, "Prosecutions, Politics and the Public Interest: Some Recent Developments in the U.K., Canada and Elsewhere" Criminal Law Quarterly 55, no. 4 (2010): 449-78, at 463-67.

35 For example, according to the Public Prosecution Service of Canada Deskbook, areas in which public interest consultations "may be warranted...include, but are not limited to: cases before the Supreme Court of Canada; larger scale environmental prosecutions; challenges to the constitutionality of federal legislation; war crimes, crimes against humanity and genocide prosecutions; and cases involving official language rights, aboriginal law or national security issues"; Canada, Public Prosecution Service, Public Prosecution, Part 1.3. p. 3. 
higher standard of conduct for the AG, and jeopardizing the public interest in the process.

Critics may respond that making consultation mandatory will only undermine the prosecutorial independence of the AG, but it is not at all clear this worry is justified. Certainly, if consultation came to be regarded as a constitutional obligation, it would provide a stronger incentive for the AG to engage with ministers who might have useful information or insights to offer, and indeed this is precisely the reason for regarding it as an obligation in the first place. Correspondingly, in line with Lord Asquith's observations, cabinet and the prime minister could now cite a legitimate entitlement to be consulted when the circumstances warranted, and the AG could subsequently be held accountable for failing to engage in those consultations. Nevertheless, this would not alter the fundamental fact that final decisionmaking authority on public prosecutions, which includes the decision whether or not to heed the advice gained through ministerial or prime ministerial consultations, would continue to be exercised exclusively by the AG. As Edwards reminds us, "it is one thing to expect the Attorney-General when confronted with cases of a political character to ascertain and be guided by the views of the Cabinet or of the appropriate executive authority; it is altogether a different matter to demand of the Attorney-General that he act in such cases strictly in accordance with the views or decisions of the executive." 36

Granted, there will always be the risk that ministers or the prime minister may abuse their authority and attempt to subvert the prosecutorial independence of the AG on partisan grounds, but this risk is already present within the existing constitutional framework of prosecutorial independence, and there is no reason to think it would increase by shifting to a framework where consultation was regarded as the AG's constitutional duty. ${ }^{37}$ The best way to mitigate this risk is not by continuing to insist on the principle of non-obligatory consultation, with all its attendant defects, but by ensuring that appropriate safeguards for the prosecutorial independence of the AG are in place. Here, it is difficult to disagree with the prevailing scholarly consensus that the best such safeguard is the assurance that the AG is an individual of the utmost integrity and strength of character, who is prepared to resist any effort to compromise the fair and objective exercise of their prosecutorial discretion. ${ }^{38}$ The AG also holds the power of resignation and its capacity to trigger a storm of parliamentary and public investigation into any potential interference with their independence. ${ }^{39}$ The accountability of ministers to

Edwards, The Law Officers, 214-15.

As Edwards concludes, this risk is present in virtually every institutional configuration of prosecutorial independence, and it is unlikely it could ever be entirely eliminated; see Edwards, The Attorney General, 67; John Edwards, "The Charter, Government and the Machinery of Justice," University of New Brunswick Law Journal 36 (1987): 41, at 50-51.

Edwards, The Attorney General, 57; Edwards, "Ministerial Responsibility," 72; Edwards, "The Charter," 50; Stenning, "Discretion, Politics," 364; Rosenberg, "The Attorney General," 816; I. G. Scott, "Law, Policy," 119-20; Roach, "The SNC Lavalin Controversy," 6.

39 Edwards, The Attorney General, 378-79; Rosenberg, "The Attorney General," 819-20. There is of course no guarantee that the AG will always live up to this standard of conduct, but such a guarantee is not to be had in any alternative configuration of the office of the AG, and for all its shortcomings I agree with Edwards, "The Charter," 50-51, that maintaining the AG as an elected 
parliament and ultimately to the Canadian public offers another powerful safeguard against potential abuse, and this mechanism could be strengthened by a requirement that any public interest consultations undertaken with the AG be "documented and minuted" to better ensure their transparency. ${ }^{40}$ Such a requirement would arguably incentivize higher standards of conduct from public officials, who would know beforehand that their interventions with the AG would be readily available for parliamentary and ultimately public scrutiny. ${ }^{41}$

\section{Public Interest vs. Partisan Political Considerations}

Another question closely connected to whether consultation is an option or an obligation for the AG is: what sorts of considerations can and cannot legitimately be raised by ministers or the prime minister in the course of those consultations? The answer, according to Shawcross, is that they should restrict themselves to matters relating to "the effect which the prosecution, successful or unsuccessful as the case may be, would have upon public morale and order, and ... any other considerations affecting public policy." 42 In other words, ministers can legitimately raise matters germane to a prosecution's impact on the public interest. ${ }^{43}$ This is in line with a core axiom of Canadian criminal law, which is that the public interest is not always served by prosecution, even where the evidence exists to support it. ${ }^{44}$ Central to this point of guidance is a vital distinction between legitimate public interest considerations and inappropriate partisan-political considerations which must be excluded from the exercise of prosecutorial discretion. ${ }^{45}$

The classic rendering of this distinction comes from Edwards, who defines legitimate public interest issues as those which speak to "the wider interests of the public at large." 46 In other words, we are talking about issues that affect either the advancement of vital public goods or public well-being, and/or the prevention or mitigation of serious public harms, irrespective of any considerations of political loyalty or party allegiance. Edwards's own list of examples includes the "maintenance of harmonious international relations between states, the reduction of strife between ethnic groups, [and] the maintenance of industrial peace." 47 To this one might add safeguarding national security, the mitigation of severe economic or financial crises, public health initiatives to reduce harm to vulnerable populations

member of cabinet strikes the most appropriate balance between AG independence and AG accountability; see also Roach, "Prosecutorial Independence," 501-503; and McLellan, "Review of the Roles," 22-31.

40 full set of recommendations on ministerial public interest consultations see pp. 32-37.

41 On the role of accountability in preserving the integrity of the office of the AG and the criminal justice process more generally, see Edwards, The Attorney General, 379, 477-78; Edwards, "The Charter," 50-51; Canada, Law Reform Commission, "Controlling Criminal Prosecutions," 13; McLellan, "Review of the Roles," 15-16; and Rosenberg, "The Attorney General," 820.

42 United Kingdom, House of Commons Debates, vol 483, cols 683-84.

43 See Rosenberg, "The Attorney General," 821.

44 Ibid., 827, 830; Canada, Public Prosecution Service, Public Prosecution, Part 2.3, p. 5.

45 Canada, Law Reform Commission, "Controlling Criminal Prosecutions," 13; McMurtry, "The Office," 2-3, 6; Edwards, “The Charter,” 47-48; Krieger v Law Society, s 30.

46 Edwards, "The Charter," 48; Edwards, "Ministerial Responsibility," 69-70.

47 Edwards, "Ministerial Responsibility," 70. 
(e.g., those living with HIV), or the harm-mitigation considerations contemplated by the remediation agreements provisions of the Criminal Code. ${ }^{48}$

Partisan considerations, in contrast, encompass “anything savoring of personal advancement, of personal sympathy or hostility felt...towards a political colleague, political supporter or opponent, or which relates to the political fortunes of [the] party or the government in power." ${ }^{49}$ Examples from the SNC-Lavalin affair include the references by Trudeau and Wernick to the impact of prosecution on the pending Quebec and federal elections, Trudeau's more specific reference to being an MP from a federal riding in close proximity to SNC-Lavalin's Montreal headquarters and, perhaps most blatantly, the remark from Trudeau's senior legal advisor, Matthew Bouchard, that "We can have the best policy in the world but we need to be re-elected." ${ }^{50}$ Other examples might include efforts to shield a political colleague from the personal and political consequences of a legitimate prosecution or to weaken or persecute one's political opponents or their supporters.

More than one analyst has remarked on the challenge of applying this distinction in practice, and the fact that it is not always easy to cleanly distinguish between the partisan and public interest considerations in play. ${ }^{51}$ Nevertheless, the essential standard established by this distinction - that the exercise of prosecutorial discretion is intended to serve the interests and well-being of members of the general public, irrespective of questions of party allegiance, political reward or punishment, or political survival-is not difficult to grasp, and it continues to be widely endorsed by scholars, jurists, and political practitioners. ${ }^{52}$ It is somewhat ironic, therefore, that Federal Ethics Commissioner, Mario Dion, seriously misconstrues this distinction in his report on the SNC-Lavalin affair. Dion is on solid ground when he takes Trudeau and his advisors to task for attempting to sway the AG's decision on the SNC-Lavalin file with partisan political (i.e., electoral) considerations, ultimately concluding that these efforts " $r[a] n$ counter to the principle of prosecutorial

48 See Edwards, The Attorney General, 467-68; Stenning, "Prosecutions, Politics," 461-62, 467n56; Roach, "Prosecutorial Independence," 490-91; Canada, Public Prosecution Service, Public Prosecution, Part 5.12, pp. 2-3; Canada, Criminal Code (RSC, 1985, c C-46), Part XXII.1, at 715.31(f); and Jull, "The Right and the Wrong Way," 9-10.

Edwards, "The Charter," 47-48; cf. McMurtry, "The Office," 2-3; Rosenberg, "The Attorney General,” 821-23, 840; I. G. Scott, "Law, Policy,” 121.

50 As reported in Dion, Trudeau II Report, 16-18, 25-26, 42. For a different perspective on these representations see Bezanson, "Constitutional or Political," 803-804.

51 See Canada, Law Reform Commission, "Controlling Criminal Prosecutions," 13; Stenning, "Discretion, Politics," 341; I. G. Scott, "Law, Policy," 121; Roach, "Prosecutorial Independence,” 492. For an illuminating historical view on these matters see Jonathan Swainger, The Canadian Department of Justice and the Completion of Confederation (Vancouver: University of British Columbia Press, 2000), 19-35.

52 See McMurtry, "The Office," 2-3, 6; Rosenberg, "The Attorney General," 821-23; Canada, Privy Council Office, Open and Accountable Government, 2015, s. F.5, https://pm.gc.ca/sites/pm/files/ inline-files/oag_2015_english.pdf; Roach, "The SNC Lavalin Controversy," 1-3; McLellan, "Review of the Roles," 10-11. While I agree with Swainger that determinations of the public interest in the context of criminal prosecutions are unavoidably political in that they are inevitably influenced by the political values, ideals, or outlooks of decision-makers (on this point see also Edwards, "The Charter," 48), contra I. G. Scott ("Law, Policy," 121), the mere fact that they are political does not automatically render them partisan in the sense in which that term is defined here. The line between political and partisan is crossed only when such decisions become mere tools in the service of party interests or the pursuit of party power. 
independence and the rule of law." 53 However, his analysis of the appropriate relationship between public and private interests in deliberations over the exercise of prosecutorial discretion has troubling implications for how we view the future role of government ministers in public interest consultations with the AG. ${ }^{54}$

To elaborate, Dion entertains the possibility that the sorts of concerns over the potential loss of jobs, pensions, etc. raised by Trudeau and other government officials were valid public interest considerations, but goes on to argue that because these public interests were "inextricably linked to SNC-Lavalin's private interests....Trudeau could not properly put forward any arguments involving public or private interests to the Attorney General." ${ }^{55}$ Now it may very well be true that, in this particular case, Trudeau and his advisors were motivated to raise the private interests of SNC-Lavalin (and its employees, pensioners, and shareholders) primarily for improper partisan rather than legitimate public interest reasons, but Dion draws a much more sweeping conclusion in his report. For while the commissioner acknowledges that virtually every legitimate exercise of official power potentially advances some private interest, and that in many cases this is entirely unobjectionable, ${ }^{56}$ when it comes to ministerial consultations on the AG's exercise of prosecutorial discretion, his position is that any such interconnection between the public and private interests in play must be regarded as inherently and irredeemably problematic. In other words, he regards as improper any attempt by a minister (or prime minister) to make otherwise legitimate public interest representations to the AG whenever those representations would also advance a private interest, regardless of whether the advancement of that private interest was incidental (or secondary) to the minister's primary goal of advancing the public interest, and irrespective of whether the minister believes that the public interests at stake are of sufficient importance to justify the advancement of that private interest.

With all due respect to the commissioner, this broader conclusion must be rejected. In his report, Dion fundamentally mischaracterizes Edwards's original distinction between partisan interests and the broader public interest by using the term "private" interchangeably with "partisan" as a descriptor of representations automatically regarded as illegitimate in relation to the exercise of prosecutorial discretion. ${ }^{57}$ However, what makes a representation partisan in this context is not merely the fact that it would benefit some private party, but rather that its sole or

53 Dion, Trudeau II Report, 54, also 53.

54 On this point, see also Errol Mendes, "Did the Ethics Commissioner Misinterpret His Own Act and Jurisdiction?” iPOLITICS, Aug 15, 2019, https://ipolitics.ca/2019/08/15/did-the-ethicscommissioner-misinterpret-his-own-act-and-jurisdiction/; and the interview with Mendes in Ian Austen, "A Watchdog Found Trudeau Broke the Law, but Not Everyone Agrees," New York Times, August 16, 2019, https:/www.nytimes.com/2019/08/16/world/canada/trudeau-snc-ethics. html.

55 Ibid., 51, also 57.

56 Ibid., 46.

57 See Dion, Trudeau II Report, 45-46, 53, and compare Edwards, "Ministerial Responsibility," 70; for commentary on this point see Kent Roach, "Can Prosecutorial Independence and the Public Interest Ever Truly be Reconciled?" Globe and Mail, August 15, 2019, https://www. theglobeandmail.com/opinion/article-can-prosecutorial-independence-and-the-public-interestever-truly-be/. 
primary intended purpose is to advance that private interest as a means of rewarding (or shielding) a political supporter so as to gain some direct or indirect political advantage thereby. Conversely, representations aimed fundamentally at advancing a genuine and pressing matter of public interest but which would necessarily (or unavoidably) serve some private interest on the way to securing that objective cannot reasonably be regarded as politically partisan, and thus there are no good grounds for ruling them impermissible under the Shawcross doctrine. Again, the AG must still be the one who finally decides how (or whether) such considerations will ultimately factor into the exercise of prosecutorial discretion, but the key point is that they will be brought to the attention of the AG, who might otherwise not have been aware of them or fully grasped their significance.

To appreciate this point is to understand the weakness, and possibly even the danger, of Commissioner Dion's much more restrictive reading of the Shawcross doctrine. It is the same weakness that afflicts the idea of optional consultation, namely, that it needlessly increases the risk of depriving an AG of information and insights essential to a properly informed determination of the public interest. For in cases where the public and private interests surrounding a politically sensitive prosecution cannot be fully disentangled, and it is difficult to imagine many cases in which this would be possible, ministers with critical information to offer might simply refrain from doing so, fearing that their efforts to serve the public interest would automatically be perceived as an illegitimate attempt to smuggle self-serving partisan considerations into the exercise of prosecutorial discretion. ${ }^{58}$

\section{Ministerial Conduct in Public Interest Consultations}

What standard of conduct is expected of ministers engaged in public interest consultations with the AG? According to Lord Shawcross, ministerial input is "confined to informing [the AG] of particular considerations, which might affect his own decision, and does not consist, and must not consist in telling him what that decision ought to be. The responsibility for the eventual decision rests with the Attorney-General, and he is not to be put, and is not put, under pressure by his colleagues." 59 This seems clear enough on its face, but one of the key points to emerge from the SNC-Lavalin affair is that there is a lack of consensus on what constitutes inappropriate pressure, and on the standards governing the interactions of ministers and the AG in public interest consultations more generally.

Some analysts have adopted a rather more conservative perspective on this question. For example, Scott argues that the very act of ministers independently initiating consultation in itself rises to the level of inappropriate political pressure that threatens the prosecutorial independence of the AG and must be strictly avoided. However, this argument seems oblivious to the risk that vital public interest considerations could be neglected simply because the AG is not aware of them and the relevant ministers are forbidden from proactively raising them. ${ }^{60}$

\footnotetext{
For similar concerns, see Roach, "Prosecutorial Independence."

United Kingdom, House of Commons Debates, vol 483, cols 683-84.

Craig M. Scott, "The Justice Minister/Attorney General's Dual Role Requires a High Degree of Independence. A Full Accounting of The SNC-Lavalin Affair is Required," Policy Options,
} 
Even those who are more open to the idea of ministers initiating consultation frequently insist on a number of stringent qualifications that tightly constrain this practice. These include the requirement that consultation initiated by the AG be the default standard to be followed, with ministers taking a back seat in the process, ${ }^{61}$ the stipulation that ministers always be leery of making unsolicited representations because an AG would have great difficulty dissociating "genuine public interests from partisan interests when those considerations are advanced by Cabinet colleagues," 62 and finally, the proviso that even in those few exceptional circumstances where ministers might legitimately request consultation, the AG be under no obligation to accede to that request, regardless of its substantive content or level of importance. ${ }^{63}$

I find this more conservative perspective problematic. As former AG of Canada Ron Basford rightly concludes, it is the duty of the AG "to ensure that the widest possible public interests" are taken into account in the exercise of prosecutorial discretion. ${ }^{64}$ This purpose is ill-served by a normative constitutional framework that threatens to constrict when it really should serve to expand the AG's exposure to information and expertise in the possession of members of cabinet. To ensure the most rigorous and thoroughly informed assessment of the impact of prosecutorial decisions on the public interest, we would be better served by a normative constitutional framework that accords ministers an equal freedom, and an equal responsibility, to initiate public interest consultations when the circumstances demand, and wherein it is understood that the AG has an obligation to engage in those consultations whenever there are reasonable grounds to conclude that ministers might have useful information or advice to offer. I would argue further that this normative framework should welcome, even encourage, respectful contestation and debate amongst ministers, the prime minister, and the AG in determining the public interest merits of prosecution, and, if conducted with the requisite integrity, objectivity, and transparency, this process should be regarded not as a threat but as a valuable check and balance on the independence of the AG and an indispensable form of quality control on the exercise of prosecutorial discretion. ${ }^{65}$

This brings us to a question that cuts to the very core of prosecutorial independence: at what point does appropriate communication, contestation, and debate cross over into inappropriate pressure? While there is virtually unanimous agreement amongst analysts that the AG is not to be ordered, directed, or in any other way compelled by any government official while exercising their

February 12, 2019, https://policyoptions.irpp.org/magazines/february-2019/trust-us-doesnt-cutsnc-lavalin-affair/.

61 Edwards, The Attorney General, 32; Dion, Trudeau II Report, 53; McLellan, "Review of the Roles," 35.

62 Dion, Trudeau II Report, 53.

63 McLellan, "Review of the Roles," 35.

64 As paraphrased in Edwards, "Ministerial Responsibility," 68.

65 See Brian Greenspan, "Did Jody Wilson-Raybould Understand Her Role as Attorney-General?" Globe and Mail, April 17, 2019, https://www.theglobeandmail.com/opinion/article-did-jody-wil son-raybould-understand-her-role-as-attorney-general/. 
prosecutorial discretion, ${ }^{66}$ clear differences emerge when it comes to other manners of communication. For some, any form of contestation and debate over the public interest merits of prosecution, no matter how respectful or collegial, is already going too far. This includes Edwards, who argues that it would be inappropriate for any cabinet minister or the prime minister to offer an opinion on how the AG should decide any given case, whether this be in the form of a specific recommendation or simply an expression of opposition to the AG's own proposed course of action. ${ }^{67}$ Similarly, Dion sees no room in the Shawcross doctrine for debate between the AG and other members of cabinet, and he regards any attempt to influence the AG's perception of the public interest merits of prosecution as a violation of prosecutorial independence. ${ }^{68}$ This view is shared by Scott, who argues that ministers invited for consultation must avoid any form of communication suggesting the desirability of a particular course of action, restricting themselves to a "measured outlining of relevant considerations," which again leaves the business of weighing and deliberating upon the merits of those considerations exclusively in the hands of the AG. ${ }^{69}$

From this perspective, then, inappropriate pressure comprises not only attempts to compel the AG to make a particular decision, but also attempts to influence or persuade the AG as to the merits of a given course of action, and any expression of opinion for or against such a course of action. I see two problems with this perspective, the first of which speaks to its plausibility. For though it is possible to imagine ministers providing neutral, measured, and entirely dispassionate input in cases that are relatively uncontroversial and where the stakes are not very high, it seems far less plausible in more difficult and complex cases where the stakes are elevated, sometimes dramatically. Edwards himself appears to acknowledge as much in stating that " $[\mathrm{h}]$ owever one attempts to delineate in unequivocal language the boundary line between what is proper and improper in these kinds of exchanges between ministers and the Attorney General it must be acknowledged that there will be occasions in which both the contents and manner of communicating factual information as to the likely effects of different courses of action is tantamount to expressing an opinion on the appropriate choice that should be made." ${ }^{70}$ In especially challenging cases, for example those involving potential threats to national security, where there are serious risks to the lives or livelihoods of citizens, or where the potential for a miscarriage of justice is high, I would argue that it is entirely natural, and indeed laudable, that ministers would feel a duty to communicate the overriding importance or urgency of the considerations they are raising, to express an opinion on the merits of some courses of action and the dangers of others, and in so doing to try to influence the AG's opinion on the prosecutorial course of action that would best serve the public interest.

66 Edwards, "The Charter," 48-49; I. G. Scott, "The Role," 189-90; Roach, "The SNC Lavalin Controversy," 1; Dion, Trudeau II Report, 53, 56; and McLellan, "Review of the Roles," 33.

Edwards, The Attorney General, 323-24, 386.

Dion, Trudeau II Report, 39, 53, 55.

C. M. Scott, "The Justice Minister."

Edwards, The Attorney General, 324; cf. Edwards, The Law Officers, 219. 
A second problem with this perspective is that it places too much faith in the judgment and capabilities of the AG and not enough in that of other ministers or the prime minister. As we know already, prosecutorial independence and the rule of law rely heavily on the wisdom and the integrity of the AG, but the very fact of this reliance points to the dangers of placing the AG behind a protective firewall, insulated from any form of critical engagement or debate with members of cabinet. Attorneys general are not infallible, and thus are not immune to oversights or errors of judgment and, in some situations, may simply lack the background or expertise necessary to fully grasp the nature and gravity of the situation they are confronting. ${ }^{71}$ As with other Crown law officers and so with the AG, there may also be rare occasions when the exercise of prosecutorial discretion is distorted by "tunnel vision, racism, or stereotypes about either the accused or victims," 72 or is skewed by considerations of a more purely partisan nature. Rare though such situations may be, if or when they do arise, the public interest and the fair administration of justice can only benefit from the presence of ministers and a prime minister who are prepared to challenge and engage the AG in rigorous debate on matters of both fact and principle, who will not hesitate to communicate their firm opposition to prosecutorial courses of action they regard as seriously misguided or harmful, and who will serve as forceful, yet principled, advocates of prosecutorial courses of action that are more conducive to public well-being and the integrity of the criminal justice system. $^{73}$

All such interactions should be respectful and must always be predicated on the baseline assumption that final decisions on matters of public prosecution will be made by the AG alone. ${ }^{74}$ They should not, on the other hand, be excessively timid or deferential. If they are to be meaningful, and beneficial, public interest consultations within government may, at times, need to be difficult, intense, even heated, and all the more so when there are honest, and highly consequential, differences of opinion as to which prosecutorial course of action would best serve the public interest. Public interest consultations can be all of these things without violating the Shawcross prescription against exerting pressure on the AG. ${ }^{75}$ The McLellan report offers a helpful standard for distinguishing between inappropriate pressure and tough but legitimate discussions among ministers and the AG:

In my view, "pressure" here refers to threats, implied or explicit, that a decision by the Attorney General would result in a negative consequence for the Attorney General - for example, that their position in Cabinet or in the party could be at risk. Pressure could also come in the form of enticements or promises of a benefit. Persistence would also be a factor to be considered. The term "pressure" does not, however, refer to the kind of vigorous discussions

\footnotetext{
71 See Stenning, "Discretion, Politics," 360-62; Stenning, "Prosecutions, Politics," 463-66.

72 McLellan, "Review of the Roles," 28. McLellan makes this point with reference to prosecutors whose actions are reviewable by the AG, but I see no reason why it should not also apply to the AG.

73 For an argument along these lines see Greenspan, "Did Jody Wilson-Raybould."

74 Edwards, The Attorney General, 56-57; McLellan, "Review of the Roles," 34, 37.

75 McLellan, "Review of the Roles," 34, 36.
} 
between members of the government that is common and, indeed, desirable to understand fully the public interest. ${ }^{76}$

For example, Michael Wernick's comment to Jody Wilson-Raybould that he wanted her to be aware that the Prime Minister was in the kind of mood on the question of securing a deferred prosecution agreement where he was "going to find a way to get it done, one way or another" is a clear candidate for inappropriate pressure, in its intimation that Wilson-Raybould's tenure as AG could be jeopardized by her failure to heed this message. ${ }^{77}$ On the other hand, calling upon an AG to explain why a deferred prosecution agreement is not on the table when there are pressing public interest reasons for doing so or firmly challenging an AG's assessment of the potential risks of prosecution to innocent third parties would not be in violation of this standard, again so long as partisan considerations are strictly avoided and the right of the AG to make the final decision is respected. ${ }^{78}$

Persistence is a somewhat more complicated factor to consider, though it can be stated from the outset that persistence does not automatically constitute inappropriate pressure. For example, if an AG initially declines a request for consultation from a minister in possession of information with critical bearing on the public interest merits of a given prosecution, then a degree of persistence on the part of that minister would seem to be justified. Indeed, it would arguably be irresponsible for a minister simply to abandon any further attempt to bring that information to the AG's attention, especially if the stakes are high. Similarly, once the process of consultation has been engaged, the very idea of vigorous discussion and debate implies a certain measure of persistence on the part of ministers presenting arguments and counterarguments in the hope of influencing the AG's conclusion on the course of action most conducive to the public interest. However, in cases where the AG has carefully and thoughtfully considered the information and arguments presented by cabinet and/or the prime minister and has nevertheless decided on an alternative course of action, there will obviously come a point when continued persistence crosses the line into inappropriate pressure, as arguably occurred in the SNC-Lavalin affair.

Although it is impossible to draw this line with absolute precision, McLellan suggests another helpful way of thinking about the term pressure, which is to ask: "would a reasonable person believe that the Attorney General might be influenced to change their position for reasons unrelated to the public interest as a result of a comment or suggestion, whether express or implied?"79 For example, repeatedly pushing the same argument that an AG has already thoroughly considered, debated, and rejected would almost certainly qualify as inappropriate pressure if the intention was simply to wear down their resolve or to signal that, without a

76 McLellan, "Review of the Roles," 36-37. Roach, "Prosecutorial Independence," 497-99, also supports the idea of "robust, probing and candid" public interest consultations amongst the AG and other government ministers.

77 Dion, Trudeau II Report, 33-34, 43-44. See also Wilson-Raybould, Evidence Presented, 2, 6, 11. Compare Bezanson, "Constitutional or Political," 803-804.

78 To be clear, I am making a general point here, not an argument about what did or did not justifiably transpire during course of the SNC-Lavalin affair

79 McLellan, "Review of the Roles," 36-37. 
change of heart, their days as AG were numbered. On the other hand, repeated ministerial interventions in a context where the facts and circumstances underlying a case were rapidly evolving in ways that significantly affected the public interest calculations might very well be appropriate and justified. ${ }^{80}$

Admittedly, holding the line between legitimate but vigorous interventions and the exercise of inappropriate pressure by ministers engaged in public interest consultations with the AG will not always be easy, especially when the stakes for the public interest are high and the risk to the political fortunes of the government are, accordingly, elevated. Nevertheless, this is by no means an impossible task, and with appropriate safeguards in place to ensure these consultations are conducted openly and transparently and are appropriately documented and reviewable, there is every reason to be confident that participants will either abide by the standards of conduct expected of them or be held accountable when those standards are transgressed.

\section{Conclusion}

Constitutional democracies dedicated to the rule of law and the fair and impartial administration of criminal justice place a premium on safeguarding the prosecutorial independence of the AG, and for good reason. An independent AG is critical to ensuring that the criminal justice system remains dedicated to serving the public interest and is used neither as a vehicle for advancing the partisan interests of the governing party or their supporters, nor as a weapon for persecuting or punishing political opponents. Nevertheless, respect for the principle of prosecutorial independence does not, and should not, require a posture of comprehensive deference to the authority commanded by the AG in the domain of criminal prosecutions. ${ }^{81}$ On the contrary, following Rosenberg, we must always be prepared to "re-evaluate the limits and value of $[A G]$ independence... [and to] consider how that independence can be better balanced with greater openness, accountability and transparency." 82 In this article I have taken up this challenge in light of the many questions raised by the SNC-Lavalin affair. In so doing I have defended an approach to prosecutorial independence that balances respect for the AG's authority to make final decisions in matters of criminal prosecution against a more vigorous and proactive role for cabinet and the prime minister in the public interest consultations informing the exercise of the AG's prosecutorial discretion, including their right to bring forward vital public interest considerations that are inextricably linked to the potential advancement of private interests. The strength of this approach, I believe, is that it refuses to rely too heavily on the judgment, capabilities, or integrity of either the AG, the prime minister, or members of cabinet. Instead, it places its faith in a normative constitutional framework ${ }^{83}$ that emphasizes the mutually

80 This was a significant point of debate in the SNC-Lavalin affair. See, Dion, Trudeau II Report, 20, 31, 34, 53; Wilson-Raybould, Evidence Presented, 2.

81 See Roach, "Prosecutorial Independence," 505-506; Roach, “The SNC Lavalin Controversy," 3-4.

82 Rosenberg, "The Attorney General," 850.

83 One important question I have not addressed in the article is how this alternative normative framework might be effectively institutionalized. This is a topic that deserves a paper of its own, but 
228 Michael Murphy

interdependent nature of the roles these figures occupy as guardians of the public interest-a responsibility that exists within a broader system of checks and balances that includes accountability to parliament, and ultimately to the public whose interests they are constitutionally bound to serve. ${ }^{84}$

Dr. Michael Murphy

Professor, Department of Political Science, University of Northern

British Columbia

michael.murphy@unbc.ca

one promising option might be its incorporation into the sort of ministerial education programs and revisions to the Open and Accountable Government (Canada, Privy Council, 2015) document recommended by McLellan ("Review of the Roles," 40-42).

84 My use of the checks and balances language was inspired by Roach, "Prosecutorial Independence," 500-503. 